\title{
Effects of Waste Dumps on Stream Water Quality in Rural Areas of Southern Nigeria
}

\author{
Obeta Michael C.; Ochege, Friday Uchenna \\ Hydrology And Water Resources Unit Department Of Geography University Of Nigeria, Nsukka \\ Environmental Management Unit Department Of Geography University Of Nigeria, Nsukka
}

\begin{abstract}
This paper focuses on the effects of waste dumps on stream water quality in rural areas of southern Nigeria. The purpose was to evaluate evidence linking surface water pollution to leachate migration from waste dumps. Thirty-two water samples were collected and analysed from eight waste dumpsite environments located on eight widely separated streams. The samples were evaluated for physical, chemical and bacteriological contamination. Eighteen water quality parameters were investigated. The parameters included $\mathrm{pH}$, total hardness, sulphate, alkalinity, manganese, silica, potassium, total dissolved solids, iron, nitrate, calcium, total suspended solids, chloride, magnesium, turbidity, biochemical oxygen demand, Escherichia coil and total coliform count. Results of the analysis revealed the degree of stream water pollution, the critical pollutants and the strategies for managing polluted stream water in the study area. The streams are polluted at many locations and consuming them portends danger from water borne diseases. Eight water quality indicators returned mean values that exceeded the 2011 WHO and NAFDAC standards for drinking water. Strategies which may help to remedy the situation were recommended.
\end{abstract}

Key Words:Domestic water uses, human health, pollutants, stream water quality, waste dumps, source protection.

\section{Introduction}

Numerous studies have examined the association between stream water quality and human activities particularly since the proclamation of the Worlds Drinking Water Supply Decade in the 1990s, (Ocheri et al, 2008). Some of these studies have reported increased risk of illness to those who are associated with exposure to pollutants migrating from waste dumps (Aliyu, 2008). Ocheri et al (2008) established a strong correlation between the degree of stream water pollution and the frequency of waste dumps in the stream environment. Toxic substances that have high concentration of nitrate, phosphorus and other pollutants derived from solid wastes can filter from a dumpsite and contaminate the stream waters. In fact, Uting et al (2008) observed that pollution level and water associated infections in their study area were both proportional to the duration of exposure to contaminants. They noted that swimmers in the studied, polluted streams were exposed to pathogens, toxins and irritants that cold easily enter the ears, eyes, nose and mouth as well as the anus and genitourinary tracks. In addition, they were exposed to a variety of other health problems including dermatitis and skin infections or deep tissue and blood infections through open cuts. Consumers of polluted stream water also suffer from gastrointestinal, respiratory, dermatologic, throat, and other diseases depending on the concentration of pathogens and duration of exposure (Nzeadibe, 2009).

Contamination of surface waters represents a growing environmental health challenge in several regions around the globe (Ocheri et al, 2008). Uting et al (2007) noted that surface water pollution is a major environmental problem in many developing countries and that it is mainly due to human activities resulting from rapid population growth and increased productive activities. One of such human activities that currently threaten the quality of stream waters is the age-old practice of dumping wastes into or along stream channels. Generally open waste dumps are the oldest and commonest way of disposing solid wastes in many areas (Nzeadibe, 2009). In recent years, there has been a phenomenal increase in the quantity and frequency of solid waste generated and dumped in streams in many developing countries (Aliyu, 2008). This development is a source of public concern, especially in areas where surface water bodies account for a high proportion of the peoples water needs.

In Nigeria, contamination of surface water sources is a major environmental issue that attracts a lot of interest because of the importance of water quality on human health and on environmental quality (Obeta and Ajaero, 2010). Pollution of surface water sources occur in both urban and rural areas (Ikem, et al, 2000). Leachate and other pollutants from waste dumps migrate into surface waters and pollute them. In the rural areas, water scarcity and poor quality of drinking water from natural sources such as rivers and streams are major challenges facing the inhabitants of most communities (Bichi, 2000). The problem is even more acute in communities that lack access to piped water supplies and so must depend on wells and steam water. The health of the people depends largely on the quality of the water they drink and so water contamination is a serious 
concern to water authorities because of the health implications (Aniah, and Utang, 2006). Indeed, Olaniyan, et al (2009) noted that a number of dumpsites have been implicated for chemical and bacterial contamination of drinking water sources, in some cases, causing poisoning, cancer, heart diseases and teratogenic abnormalities. The migration and release of pollutants from waste dumps into streams pose a high risks to surface water users. The danger associated with dumpsites is that they may contain highly toxic substances, which when flushed down into streams, may lead to ingestion of dangerous pathogens. Literature evidence suggests a global increase in the frequency, magnitude and geographic extent of surface water contamination (Jeong, 2001). Comparatively little work has been reported on contamination of surface waters by leachate migration from dumpsites in various parts of Nigeria. Our primary goal in this study, therefore, is evaluate the relationship between stream water contamination and indiscriminate dumping of solid wastes. The specific objectives are to describe the level water pollution in the study area; identify and describe the critical pollutants and examine the strategies for managing polluted stream water in the study area.

\section{The Study Area}

This study was conducted in southern Nigeria. The region has an area of $312,113 \mathrm{~km}^{2}$ and lies between longitudes $2^{\circ} 49^{\prime} \mathrm{E}$ and $14^{\circ} 37^{\prime} \mathrm{E}$. The climate is tropical, with high temperatures and high humidity as well as marked wet and dry seasons. Precipitation varies widely in both time and space, ranging from less than $250 \mathrm{~mm}$ per annum in the extreme north to $2,250 \mathrm{~mm}$ at the coast. Distribution of the precipitation varies widely in terms of both space and time. The total precipitation is lowest in the extreme north, but increases towards the south, and is at its highest in the Niger Delta wetlands where it may exceed $2250 \mathrm{~mm}$ per annum. The seasonal distribution of precipitation is strongly influenced by the prevailing maritime and tropical air masses whose origin are in the ocean, (for the former) and Sahara desert for the later. Because of such distribution characteristics, precipitation is generally inadequate especially in northern parts, for urban and domestic water supplies as well as for agricultural development based on rain-fed cultivation.

The drainage density outside the coastal region ranges from moderate to low. Drainage direction is controlled by topography and joints in the basement complex, and the typical pattern at the center is dendritic. The major streams are Niger, Benue, Cross-River, Imo, Anambra, and Ogun, while the minor ones include the Adada, Abonyi, Wuse streams etc. Most of the streams are rather turbid during the rainy season owing to high dissolved and suspended sediment content (Nzeadibe, 2009). They become clearer with progressive reduction in rainfall. The major streams are perennial while their smaller tributaries dry up during the dry season. Water quality of the rivers in Nigeria is generally good at the upper reaches but deteriorate downstream (Akinbode, et al 2008).

Open dumpsites are common in the urban and rural areas in Nigeria. In the rural areas they are usually located in valleys, abandoned quarry sites, excavations and street junctions. Dumpsites located near or within streams environments enable depositors (mostly women and children) to combine the frequently re-occurring twin household chores of fetching water with that of clearing discarded materials. The observed dumpsites varied in sizes and contained a variety of solid wastes. Plastics, food waste, metals, hard papers and batteries etc. Depositors dump wastes in an uncontrolled manner and make very poor use of available space. Birds, rodents and flies are frequent "visitors" while unpleasant site and odor make it difficult for even the depositors and waste pickers to stay close to the garbage.

\section{Method of Investigation \\ (1) Choice of streams}

Eight perennial, widely-spaced streams whose watersheds are used for waste disposal activities were purposefully selected and used for this study (fig 1). The factors which informed the choice of these streams include.

1. Proximity to residential areas and

2. Accessibility. 


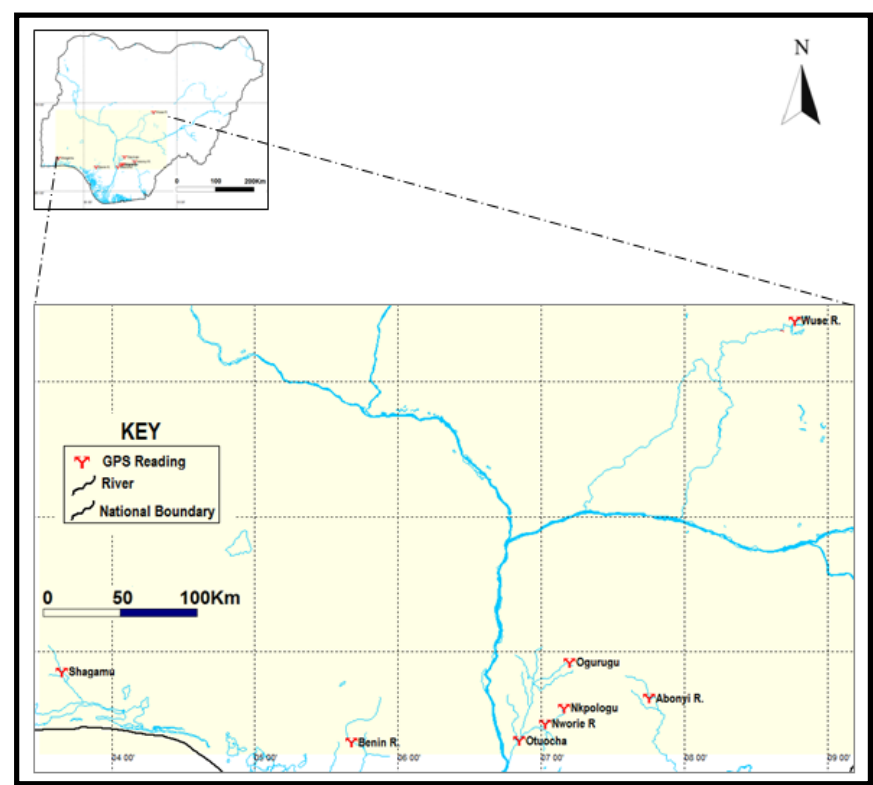

These streams are shown in table 1 .

Table 1: Streams used in the Study

\begin{tabular}{|l|l|l|l|l|l|l|}
\hline S/No & Name of Stream & Status & Host State(s) & $\begin{array}{c}\text { Sampling } \\
\text { Site or } \\
\text { Location }\end{array}$ & Nothing & Easting \\
\hline 1 & Adada River & Perennial & Enugu & Nkpologu & $06^{\circ} 30^{\prime} 19.44^{\prime \prime} \mathrm{N}$ & $07^{\circ} 07^{\prime} 12.70^{\prime \prime} \mathrm{E}$ \\
\hline 2 & Oguruogu River & Perennial & Enugu, Kogi & Ogurogwu & $06^{\circ} 54^{\prime} 42.46^{\prime \prime} \mathrm{N}$ & $07^{\circ} 12^{\prime} 22.94^{\prime \prime} \mathrm{E}$ \\
\hline 3 & Abonyi River & Perennial & Enugu, Ebonyi & Eha-Amufu & $06^{\circ} 39^{\prime} 16.54^{\prime \prime} \mathrm{N}$ & $07^{\circ} 45^{\prime} 30.92^{\prime \prime} \mathrm{E}$ \\
\hline 4 & Nworie River & Perennial & Imo & Owerri & $06^{\circ} 27^{\prime} 40.11^{\prime \prime} \mathrm{N}$ & $07^{\circ} 01^{\prime} 57.01^{\prime \prime} \mathrm{E}$ \\
\hline 5 & Ogun River & Perennial & Ogun, Lagos & Shagamu & $06^{\circ} 50^{\prime} 50.02^{\prime \prime} \mathrm{N}$ & $03^{\circ} 39^{\prime} 31.02^{\prime \prime} \mathrm{E}$ \\
\hline 6 & Anambra & Perennial & Anambra & Otuocha & $06^{\circ} 20^{\prime} 17.04^{\prime \prime} \mathrm{N}$ & $06^{\circ} 51^{\prime} 02.00^{\prime \prime} \mathrm{E}$ \\
\hline 7 & Wuse River & Perennial & Plateau & Wuse & $09^{\circ} 26^{\prime} 43.58^{\prime \prime} \mathrm{N}$ & $08^{\circ} 46^{\prime} 45.46^{\prime \prime} \mathrm{E}$ \\
\hline 8 & Ikpeba River & Perennial & Edo & Benin & $06^{\circ} 19^{\prime} 37.25^{\prime \prime} \mathrm{N}$ & $05^{\circ} 40^{\prime} 55.08^{\prime \prime} \mathrm{E}$ \\
\hline
\end{tabular}

\section{(2) Choice of water quality indicators}

Several parameters are important in the quality characterization of stream water in the study area; 18 of such parameters, shown in column 2 of table 2 were selected for investigation. The choice of these parameters was based on:

1. The project budget which did not permit inclusion of more parameters.

2. The feasibility of laboratory analysis and ease of interpretation

3. Physical properties and occurrence statistics and

4. Toxicity to human health.

Table 2: Selected Water Quality Parameters

\begin{tabular}{|c|c|c|c|c|c|}
\hline S/No & Water quality parameter & $\begin{array}{l}\text { Chemical } \\
\text { formulae }\end{array}$ & $\begin{array}{c}\text { Unit of } \\
\text { measurement }\end{array}$ & $\begin{array}{c}\text { Desirable limit } \\
\text { (WHO, 2011) }\end{array}$ & $\begin{array}{l}\text { Desirable limit } \\
\text { NAFDAC } \\
\text { Drinking H2O } \\
\text { Standard }\end{array}$ \\
\hline 1. & $\mathrm{pH}$ value & $\mathrm{pH}$ & - & $65-85$ & $6.5-8.5$ \\
\hline 2. & Hardness & $\mathrm{CaCo} 3$ & $\mathrm{Mg} / 1$ & $100-300$ & 100 \\
\hline 3. & Sulphate & So & $\sqrt{ }$ & 250 & 100 \\
\hline 4. & Sodium & $\mathrm{So}_{4}$ & $\sqrt{ }$ & NGV* & NGV* \\
\hline 5. & Manganese & $\mathrm{Mn}$ & $\sqrt{ }$ & 0.1 & 0.2 \\
\hline 6. & Silica & $\mathrm{SiO}_{2}$ & $\mathrm{~V}$ & 5.0 & $\mathrm{NGV}^{*}$ \\
\hline 7. & Potassium & $\mathrm{CoB}$ & $\sqrt{ }$ & 6.0 & NGV* \\
\hline 8. & Total Dissolved solids & TDS & $\sqrt{ }$ & - & 500 \\
\hline 9. & Iron & $(\mathrm{Fe}+2)$ & $\sqrt{ }$ & 0.3 & NGV* \\
\hline 10. & Nitrate & $\mathrm{NO}_{2}$ & $\sqrt{ }$ & 45 & 0.2 \\
\hline 11. & Calcium & $\mathrm{Ca}$ & $\sqrt{ }$ & 75 & $\mathrm{NGV}^{*}$ \\
\hline 12. & Total Suspended Solids & TSS & $\sqrt{1}$ & 250 & 500 \\
\hline 13. & Chloride & $\mathrm{Cl}$ & $\sqrt{ }$ & 250 & 250 \\
\hline 14. & Magnesium & $(\mathrm{Mg}+2)$ & $\sqrt{ }$ & 50 & 0.20 \\
\hline 15. & Turbidity & $\mathrm{C}$ & $\mathrm{Mg} / \mathrm{l}$ & 100 & \\
\hline
\end{tabular}




\begin{tabular}{|l|l|l|l|l|l|}
\hline 16. & $\begin{array}{l}\text { Thermo tolerant Coliform } \\
\text { or E.coli }\end{array}$ & Cfu & $\mathrm{Mg} / \mathrm{l}$ & 100 & NGV* \\
\hline 17. & Total Coliform Count & $\mathrm{Cfu}$ & $\mathrm{Mg} / \mathrm{l}$ & 0.2 & $\mathrm{NGV}^{*}$ \\
\hline 18. & $\begin{array}{l}\text { Biochemical oxygen } \\
\text { demand }\end{array}$ & $\mathrm{BoD}$ & $\mathrm{Mg} / \mathrm{l}$ & 50 & \\
\hline
\end{tabular}

$\mathrm{NGV}^{*}=$ No Guideline Value

\section{Sample and Sampling Techniques}

It was decided, at the planning stages, that several samples collected and tested over several months may provide more satisfactory results. Consequently, samples were collected every month., between February and May, 2012 ,to take care of changes which might occur due to variation in time, frequency of waste dumps and intensity of leachate migration. Samples were collected within dumpsites and were denoted with numbers as stations 1,2 , to 8 . The mean values of 4 samples collected within a dumpsite environment on a stream were recorded and used in the analysis. Samples were collected in $60 \mathrm{ml}$ acid-cleaned white plastic bottles with well fitted covers. The bottles containing the samples were well secured and labeled, stating source, date and time of collection. Collected samples were placed in insulated containers and transported to the water science laboratory of the Department of Microbiology, University of Nigeria, Nsukka for analysis. This laboratory was chosen due to the availability of equipment and needed expertise. Temperatures were measured directly through the use of glass thermometer and $\mathrm{pH}$ by the $\mathrm{pH}$ meter. Mean values on concentration levels of the parameters under study were first compared among each other and with the 2011 WHO and NAFDAC drinking water Standard for the characterization of stream water quality. Descriptive and inferential statistical techniques were also used to interpret the results.

\section{1.}

\section{Results and Discussion}

The Level of Stream Water Pollution in Nigeria

The range and mean values of the water quality parameters at all the stations on the streams under investigation are shown in table 3. The streams are polluted at many locations. The level of stream water pollution in the study area was interpreted by comparing the mean values of the tested water quality indicators with the 2011 WHO and NAFDAC drinking water standards. The mean values returned on the tested water quality indicators at the streams under study are shown in table 3.

Table 3: Mean Values of Obtained Water Quality Parameters

\begin{tabular}{|l|l|l|l|l|l|l|l|l|l|l|l|}
\hline S/N & Variable & $\begin{array}{c}\text { Statio } \\
\mathbf{n ~ 1}\end{array}$ & $\begin{array}{c}\text { Stati } \\
\mathbf{0 n} \mathbf{2}\end{array}$ & $\begin{array}{c}\text { Station } \\
\mathbf{3}\end{array}$ & $\begin{array}{c}\text { Statio } \\
\mathbf{n ~ 4}\end{array}$ & $\begin{array}{c}\text { Stati } \\
\text { on 5 }\end{array}$ & $\begin{array}{c}\text { Stati } \\
\text { on 6 }\end{array}$ & $\begin{array}{c}\text { Statio } \\
\mathbf{n} 7\end{array}$ & $\begin{array}{c}\text { Stati } \\
\text { on 8 }\end{array}$ & $\begin{array}{c}\text { Over } \\
\text { all } \\
\text { Mean }\end{array}$ & $\begin{array}{c}\text { WHO, } \\
\text { 2011 } \\
\text { Standard }\end{array}$ \\
\hline 1 & PH value & 7.3 & 6.6 & 6.9 & 7.4 & 7.6 & 6.8 & 7.0 & 7.5 & 7.2 & $6.5-8.5$ \\
\hline 2 & Hardness & 4.4 & 2.1 & 3.3 & 4.8 & 3.5 & 10.7 & 3.2 & 4.4 & 4.55 & 600 \\
\hline 3 & Sulphate & 1.26 & 0.92 & 1.10 & 2.35 & 1.22 & 0.89 & 0.98 & 1.64 & 1.30 & 400 \\
\hline 4 & Sodium & 13.6 & 12.3 & 9.8 & 18.07 & 29.2 & 19.5 & 14.4 & 16.1 & 16.7 & 100 \\
\hline 5 & Manganese & 0.12 & 0.01 & 0.04 & 0.06 & 0.07 & $(0.5)^{*}$ & $(0.9)^{*}$ & 0.09 & 0.3 & 0.1 \\
\hline 6 & Silica & ND & ND & ND & 18.9 & 14.2 & 0.4 & 12.2 & 6.4 & 6.5 & 100 \\
\hline 7 & Potassium & 0.85 & 1.00 & 1.43 & 2.80 & 0.66 & 0.44 & 0.97 & 1.44 & 2.0 & 5 \\
\hline 8 & Total Dissolved Solids & 128 & 72 & $(262)^{*}$ & 122 & $(258)$ & 84 & 106 & $(251)$ & 156.6 & 250 \\
\hline 9 & Iron & $(0.6)$ & 0.04 & 0.02 & 0.04 & 0.03 & 0.3 & 0.01 & 0.07 & 0.29 & 0.3 \\
\hline 10 & Nitrate & 8.0 & 4.9 & $(41.67)$ & 7.4 & 7.3 & 4.5 & $(42.76$ & 6.4 & 15.37 & 40 \\
\hline 11 & Calcium & 17.2 & 25 & 54.3 & 32.8 & 16.3 & 15.0 & 38.6 & 30.2 & 28.68 & 700 \\
\hline 12 & Total Suspended Solids & 528 & 124 & 206 & 557 & 509 & 122 & 568 & 146 & 345 & 500 \\
\hline 13 & Chloride & 8.4 & 14.8 & 18.4 & 36.4 & 6.6 & 8.0 & 14.6 & 16.2 & 12.53 & 1000 \\
\hline 14 & Magnesium & 2.68 & 2.6 & 1.8 & 3.6 & 1.6 & 2.3 & 1.6 & 3.0 & 2.40 & 100 \\
\hline 15 & Turbidity & 3.43 & $(6.14)$ & 3.49 & $(42.9)$ & 3.10 & $(5.97)$ & 3.75 & $(5.10)$ & $(9.21)$ & 50 \\
& & & $*$ & & $*$ & & $*$ & & $*$ & $*$ \\
\hline 16 & $\begin{array}{l}\text { Biochemical Oxygen } \\
\text { Demand }\end{array}$ & 3.8 & 4.6 & 5.1 & 5.1 & 6.6 & $(7.5)^{*}$ & $(7.0)^{*}$ & 4.08 & 5.52 & 7.5 \\
\hline 17 & $\begin{array}{l}\text { Escherichia coil count } \\
\text { MPN/100ml }\end{array}$ & ND & ND & $(9)^{*}$ & $(29)^{*}$ & $(0.9)^{*}$ & ND & $(3)^{*}$ & ND & $(5.24)$ & 0 \\
\hline 18 & $\begin{array}{l}\text { Total Coliform Count } \\
\text { MPN/100 mg }\end{array}$ & 0.2 & $(2.5)^{*}$ & $(11)^{*}$ & $(30.1)$ & 0 & $(2.0)^{*}$ & $(4)^{*}$ & 0.0 & $(6.23)$ & 0.2 \\
\hline
\end{tabular}

$\mathrm{ND}=$ Not detected

NGG = No guideline given 
As table 3 shows, the eight streams show distinct variations in their pollutant composition. This may be due to the variations in the geologic and vegetative environment through which they pass. Generally, the concentration levels of PH, silica, potassium, hardness, sulphate, chloride, iron, calcium and magnesium were lower than the WHO 2011 permissible limits. Nitrate concentration in two stations (Ogurugu and Abonyi rivers were relatively high, exceeding the $45 \mathrm{mg} / \mathrm{l}$ recommended by the WHO as the desirable limit of concentration for drinking water. This high concentration may probably be due to the dissolved organic nitrogen being mineralized in the banks and bed of these streams. Ogurugu and Abonyi rivers watershed are rice producing areas and fertilizer is frequently used by farmers to grow their crops. All the stations returned high mean values for total suspended solids (TSS) except stations 2, 3, 6 and 8 which returned relatively low values. These high values as observed in the field impair both the taste and appearance of the stream water.

Total dissolved solids returned high values at 3 stations. Some of contaminants such as faecal coliform count indicate that the water has been contaminated with faecal materials of man or other animals. The detection of Escherichia coli not only provides a clear evidence of pollution but also highlights the danger which the people face from the use of the streams. These pathogens can cause diseases such as typhoid, gastroenteritis, hepatitis etc. The contamination is an indicator that a health risk exists for individuals who consume the contaminated stream water.

Total coliform count ranges from $0-30.1 \mathrm{mg} / \mathrm{l}$ while Escherichia coil ranged from 0.9 to $29 \mathrm{MPN} / 100 \mathrm{mg} / \mathrm{l}$ as against the standard limit of $0.0(\mathrm{MPN} / 100 \mathrm{mg} / \mathrm{l})$. This implies that the streams at many locations are polluted and not suitable for drinking. Consuming them therefore portends danger from water-borne diseases such as dysentery, diarrhea, typhoid fever etc.

\section{The Critical Pollutants}

The critical pollutants at some of the sample stations are sodium, manganese, Total dissolved solids, Total suspended solids Nitrate, Escherichia coli and Total coliform count. Table 4 summaries the information on these critical pollutants.

Table 4: The Critical Pollutants

\begin{tabular}{|l|l|l|l|l|l|}
\hline S/No & \multicolumn{1}{|c|}{ Parameters } & $\begin{array}{c}\text { No. of stations where the } \\
\text { returned values exceeded } \\
\text { the WHO limit }\end{array}$ & $\begin{array}{c}\text { Highest } \\
\text { value } \\
\text { returned }\end{array}$ & $\begin{array}{c}\text { WHO Increase } \\
\text { Limits }\end{array}$ & $\begin{array}{c}\text { \%bove WHO } \\
\text { limit }\end{array}$ \\
\hline 1 & Total dissolved solids & 3 & 262 & 250 & 4.8 \\
\hline 2 & Iron & 1 & 0.6 & 0.3 & 100 \\
\hline 3 & Nitrate & 3 & 42.6 & 40 & 6.5 \\
\hline 4 & Manganese & 3 & 0.15 & 0.1 & 50 \\
\hline 5 & Total suspended solids & 4 & 568 & 500 & 13.6 \\
\hline 6 & Turbidity $*$ & 4 & 42.9 & 5.0 & 758 \\
\hline 7 & Total coliform count* & 5 & 30.1 & 0.2 & 14950 \\
\hline 8 & E. coli* & 4 & 29 & 0.0 & 2900 \\
\hline
\end{tabular}

* The percentage increase for these parameters are extremely highly and constitutes serious health hazards to potential consumers.

The critical pollutants at some samples stations as shown in table 4 . Column 2 of table 4 shows the number of sample stations where the returned values of the pollutants exceed the permissible limits of the WHO. The values of Escherichia coil, total coliform count, turbidity and total suspended solids exceed the WHO limits at 4 sample stations or more, while manganese and total dissolved solids exceed at 3 sample stations each. The mean value of iron and nitrate exceed only at one and two sample stations. The last column shows the percentage increase above the WHO limits. It can be seen that the values returned are high, and ranged from 6.5 to $14950 \%$. Total coliform count returned the highest \% increase of 14950 in one of the sampled stations.

\section{Management of Stream Water Pollution in the Study Area}

There is no government sponsored or enforced strategy in use by the riparian communities for the management of polluted stream water in the study area. The respondents in 3 of the watersheds had no clue on whether or the extent to which the water they collect are polluted or on how to rid the water collected of the pollutants there in. the implication of this is that pollutants in the collected stream water may not be eliminated before use. This situation is probably due to the existence of limited knowledge of the dangers of utilizing polluted stream water

In the rest of the watersheds several management strategies was found to be in use. Three of the management strategies seem to be most popular and are implemented in all the watersheds. The remaining strategies may be described as "community" or "stream" specific. Table 3 below summaries the observed/reported management strategies that are currently in use by the riparian communities 
Table 5. Respondents Identified Strategies for Managing Polluted Stream Water

\begin{tabular}{|l|l|l|l|}
\hline \multicolumn{1}{|c|}{ S/No } & \multicolumn{1}{|c|}{ Identified management strategy } & \multicolumn{1}{c|}{ Rational } & \multicolumn{1}{c|}{ Remarks } \\
\hline 1 & Use of bye-laws & $\begin{array}{l}\text { In order to prevent stream water } \\
\text { pollution communities prohibit } \\
\text { activities (defecating, etc) which in } \\
\text { their judgment can cause/worsen } \\
\text { stream water pollution within the } \\
\text { stream environment. }\end{array}$ & $\begin{array}{l}\text { Five riparian communities within } \\
\text { the stream watersheds adopted this } \\
\text { management option. }\end{array}$ \\
\hline 2 & $\begin{array}{l}\text { Zoning sections of the stream to specific } \\
\text { activities (bathing, collection of drinking } \\
\text { water, washing clothes etc) }\end{array}$ & $\begin{array}{l}\text { In order to reduce stream water } \\
\text { pollution the communities zone the } \\
\text { section of the stream they access to } \\
\text { specific uses-fermenting cassava, } \\
\text { fetch of drinking water etc. }\end{array}$ & $\begin{array}{l}\text { This management strategy widely } \\
\text { employed to reduce stream water } \\
\text { pollution }\end{array}$ \\
\hline 3 & Boiling collected water before use & $\begin{array}{l}\text { The objective is to kill some } \\
\text { dangerous pathogens contained in } \\
\text { the collected water. }\end{array}$ & $\begin{array}{l}\text { Boiling stream water before use is } \\
\text { not popular. Many regard it as a } \\
\text { waste of time }\end{array}$ \\
\hline 4 & Filtering collected water before use & $\begin{array}{l}\text { The objective is to eliminate } \\
\text { suspended/solid pollutants }\end{array}$ & $\begin{array}{l}\text { This is another stream specific } \\
\text { management strategy. As only users } \\
\text { f Ivo and Ebonyi streams use it }\end{array}$ \\
\hline 5 & $\begin{array}{l}\text { Fetching water at odd hours (either too } \\
\text { early or too late in the day) }\end{array}$ & $\begin{array}{l}\text { The objective is to collect water } \\
\text { when pollution is at its lowers level. }\end{array}$ & $\begin{array}{l}\text { This is a laborious but a widely } \\
\text { adopted management strategy. }\end{array}$ \\
\hline
\end{tabular}

\section{Recommendations}

Many of the rural communities in Nigeria still depend on wells, stored rainwater and streams for drinking water supplies. In view of this we recommend that:

(i) Where stream water is used for drinking purposes, treatment (boiling, chlorination, etc) is necessary in order to raise the stream water quality to a level where health risks are greatly minimized.

(ii) Public awareness and enlightenment programmes on the dangers of indiscriminate dumping of wastes within stream environments and of drinking untreated water should be carried out in the Nigerian rural areas through participatory workshops, extension services, radio and television programmes etc.

(iii) The rural communities should be motivated to develop and/or maintain alternative water supplies sources (deep wells, boreholes) through self-help activities.

(iv) Governments should ban or discourage indiscriminate disposal of wastes within stream environments.

\section{Conclusion}

From the results obtained, it is obvious that there is evidence of physical, chemical and biological pollutants in streams in Nigeria. Although some of the parameters tested for returned mean values, which were below the WHO limits for consumption, stream water pollution is still a serious problem that needs to be addressed because of the importance of streams as a major source of drinking water to so many communities and individuals in Nigeria. In order to meet the Millennium Development Goal of clean and quality water supply in Nigeria, the problem of surface water pollution must be addressed. Government could do this by implementing the recommendations in this paper, particularly the second which is centered on informing and educating her citizens about voluntary actions through which wastes can be managed. Households will help by improving their house keeping practices, (such as properly disposing household products) and in protecting stream environments. The government, in addition, should improve dumpsite conditions or recycle these wastes in order to minimize their negative effects on the environment.

\section{References}

[1]. ADAM, O. (2007): Governing from above: solid waste management in Nigeria's new capital city of Abuja. Stockholm: Stockholm University press. ISBN 978-91-85445-67-7

[2]. AKINBODE, O. M., ELUDOYIN, A. O., and FASHAE, O. A. (2008): Temperature and relative humidity distributions in a medium-size administrative town in southwest Nigeria. J. Env. Mgt. 87

[3]. ALIYU, B. N. (2008): Municipal Solid Waste Characteristics in three Residential Zones of Kano Metropolis: Implications for Management in the Book of Proceedings, $50^{\text {th }}$ Annual Conference of the Association of Nigeria Geographers Uni. of Calabar, August $25^{\text {th }}-28^{\text {th }}$.

[4]. ANIAH, E. J. and UTANG, P. B. (2006): Stream flow Changes and the Challenges of Traditional Ecological Responses in the most-day Region of Obudu, Cross River State, Nigeria. Global Journal of Social Sciences, 5(1): 47-52.

[5]. BALKE, KAVS-DETER and ZHO YN (2008): Natural Water Purification of Water Management by artificial groundwater recharges J. Zhejiang UNN. Sci. B. 9(3): 221-226.

[6]. BICHI, M. H. (2000): Surface Water Quality in the Kano Industrial Environment In; Falola J.A., Olofin E.A and Maiwada, A. (Eds); Land Administration of Management in Northern Nigeria, Department of Geography, Bayero Uni, Kano, Nigeria. pp.305313.

[7]. COAD, A. (2006). Solid Waste, Health and the Millennium Development Goals. Report of the CWG-WASH workshop, Kolkata, India, 1-5 February.

[8]. EDMUNDS, W.M. and GAYE, C.B. (1997): Naturally High Nitrate Concentrations in Groundwater from Sahel, Journal of Environmental Quality, Vol.26, pp.195-203. 
[9]. FEDERAL MINISTRY F ENVIRONMENT (2000). Blueprint on Municipal Solid Waste Management in Nigeria. Abuja: federal ministry of environment

[10]. GOLDFACE-IROKALIBE, I.J. (1999): The Application of Water Resources Decree to the Development and Management of River Basin Development Authorities (JL), Vol.5, No.5.

[11]. GOLDFACE-IROKALIBE, I.J. (2009): Water Management in Federal and Federal - type countries: Nigerian Perspective. (JL), Vol.9. No. 20.

[12]. GREGORY, R. and EDWARD, J. (2010): Sedimentation and Flotation, Chapter 9 in Water Quality and Treatment, $6^{\text {th }}$ Edition, AWWA and McGraw Hill.

[13]. IKEM A., OSIBANJO O., SRIDHAR, M. K. C., and SOBANDE A. (2002): Evaluation of Groundwater Characteristic near two wastes sites in Ibadan and Lagos, Nigeria Water, Air and Soil Pollution, Vol. 140, Pp. 307-333.

[14]. JEONG, C. H. (2001): Effect of Landuse and Urbanization on Hydrochemistry and Contamination of Groundwater from Taejon, Korea, Journal of Hydrology, Vol.199, pp. 239-251.

[15]. JONES, J.C. (2010): Thermal Proceedings of Waste. J.C. Jones and Ventus publishing ApS. ISBN 978-87-7681-590-5 Templeton, M.R and Butler, C. (2011): An Introduction to Wastewater Treatment. M.

[16]. MARCH BANKS, K.S. (2000): "The Effects of Urbanization and Population Growth on Stream Flow". Retrieved on 5/08/06 from http://www.geo.mau.edu/ge0333/RJS \%2Ovita\%20misc/marchbankshtm,200.

[17]. NAFADAC, (2001): National Agency for Food of Drug Administration of Control in Nigeria. Drinking Water Regulations in NAFDAC Consumer Bulletin Oct-Dec. 1(9): 87-89.

[18]. NAFDAC, (2004). Water quality standard for consumption in Nigeria.

[19]. NZEADIBE, T. C. (2009): Solid Waste Reforms and Informal Recycling in Enugu Urban Area, Nigeria. Habitat International. 33 (1) $93-99$

[20]. OBETA, M. C. and AJAERO C. K. (2010): 'The Chemical Composition of Stream Waters in Nsukka Region of Eastern Nigeria' in Igbozurike et al (Eds) Rural Water Supply in Nigeria, Cape Pub. Inp. Ltd, Owerri.

[21]. OCHERI, M. I.; MILE, Y. and OKLO, A. (2008): "Nitrate Contamination of Shallow Wells in Makurdi Urban Area of Benue State" in the Book of Proceedings, $50^{\text {th }}$ Annual Conference of the Association of Nigeria Geographers Uni. of Calabar, August $25^{\text {th }}$ $-28^{\text {th }}$.

[22]. OGBU, S. I. and ECHEBIRI, V. C. (2003): Nitrate and Nitrite content of wells in Enugu, S.E. Nigeria, Archives of Environmental Health.

[23]. OlANIYAN, I.O,; ALAYANDE, A.W.; and BAMGBOYE, O. (2009): Predicting Surface Water Contamination from Kaduna, Yola and Maiduguri landfill site. Researcher Vol.1, No.6.

[24]. ONWUGHARA, N.I, UMEOBIKA, U.C. OBIANUKO, P.N., and ILOAMAEKE, I.M. (2001): International Journal of Environmental Science of Development, Vol.2, No.1 ISSN: 2010-0264.

[25]. R. TEMPLETEON, C. BUTLER, AND VENTUS Publishing ApS. ISBN 978-87-7681-843-2

[26]. UTING, P. B.; ANDREW-ESSIEN, E.; AKINTOYE, A.O. and UPLA, P.I. (2008): "Assessing the Temporal and Spatial patterns in flow regime in Aya River, South Eastern Nigeria". Global Journal of Environmental Sciences, 7(1), 2008.

[27]. UTING, P.B.; AKINTOYE, A.O and ENYUOGU, E.B. (2007): "Watersheds Geomorphometrics in Relation to the flow regime in Aya River System of the Cross River Basin Nigeria", Global Journal of Environmental Science, 6(21): 128-134.

[28]. WHITEMAN, A. BARRANT, L. AND WESTLAKE, K. (2006): solid waste management as a catalyst for governance reforms: micro- licensing for private sector participation in Nigeria. In solid waste, health and the millennium development Goals, CWGWASH workshop 2006, 1-5 February, Kolkata, India

[29]. WILSON, D.C. VELIS, C. AND CHEESEMAN, C. (2006): role of informal waste sector recycling in waste management in developing countries. Habitat international, 30-4,797-808

[30]. WHO (1984): Guidelines for Drinking Water Quality; Health Criteria of other Supporting Information, Geneva Vol. 2.

[31]. WHO (2006): Guidelines for Drinking Water Quality; First addendum to the Third Edition Vol. 1 Recommendations, pp. 491-493

[32]. WHO (2011): Guidelines for Drinking Water Quality; $4^{\text {th }}$ Ed.

[33]. WORLD HEALTH ORGANIZATION (WHO) (2011): Guidelines for Drinking Water Quality. Fourth Edition. 